\title{
ІМУНОКОМПЕТЕНТНІ КЛІТИНИ ТА ЛОКАЛЬНИЙ ІМУНОРЕГУЛЯТОРНИЙ ІНДЕКС УРАЖЕНОЇ ТКАНИНИ ПРИ ТУБЕРКУЛЬОМІ ЛЕГЕНЬ 3 ОЗНАКАМИ АКТИВНОСТІ СПЕЦИФІЧНОГО ПРОЦЕСУ
}

\author{
๑С. Д. Кузовкова, І. В. Ліскіна, О. В. Хмель, Л. М. Загаба \\ Державна установа «Національний інститут фтизіатрії і пульмонології \\ імені Ф. Г. Яновського НАМН України», м. Київ
}

РЕЗЮмЕ. Туберкульоми на сьогодні залишаються досить поширеною формою туберкульозу легень (ТЛ). Прогресування захворювання може свідчити про неналежний контроль туберкульозної інфекції в ураженому органі на локальному рівні за можливої відсутності будь-яких системних змін імунного статусу. Ось чому принципове значення має вивчення місцевих імунних реакцій у ділянці ураження, зокрема в легеневій тканині.

Мета - встановити локальні патерни локалізації та відносну кількість антигенпрезентуючих клітин, клітин 3 антигенами M. tuberculosis та величину локального імунорегуляторного індексу в легеневій тканині при активних туберкульомах.

Матеріал і методи. Проведено імуногістохімічне дослідження серійних зрізів ділянок легеневої тканини на матеріалі 19 резектатів легень хворих із туберкульомою та морфологічними ознаками активності специфічного туберкульозного процесу.

Досліджували ділянки легеневої тканини з мікобактеріями та/або їх антигенами, а саме - грануляційний шар капсули туберкульоми, туберкульозні вогнища та гранульоми. Визначали відносну кількість CD4+ та CD8+ лімфоцитів, CD68+ клітин та клітин з наявністю антигенів M. Tuberculosis.

Iмуногістохімічне (IГX) дослідження проводили на AUTOSTAINER 360-2D виробництва компанії Thermo Fisher Scientific (США), для візуалізації клітин застосовано систему Ultra Vision Quanto HRP DAB. У роботі використано такі моноклональні антитіла фірми Thermo Fisher Scientific: мишаче CD4 Clon 4B12, кроляче CD8 Clon SP16, мишаче CD68 Clon KP1 та поліклональне кроляче Mycobacterium tuberculosis antibody PA1-7231 (Pierce Biotechnology, CШA).

Статистичну обробку даних здійснювали з використанням ліцензійних програмних продуктів, які входять В пакет Мicrosoft Office Professional 2000 (Excel).

Результати. У легеневій тканині, яку досліджували, капсула туберкульоми була представлена в усіх випадках, гранульоми поза туберкульомами визначені в 13 (68,4 \%) випадках, а туберкульозні вогнища - у 10 (52,6 \%) випадках. CD68+ клітини та макрофаги з наявністю антигенів МБТ, тобто інфіковані, виявлено у 100 \% випадків, але кількість цих клітин у різних ділянках тканини була різною.

CD8+ лімфоцити були визначені у 100,0 \% випадків у грануляційному шарі туберкульоми і туберкульозних вогнищах, та в 90,9 \% у гранульомах. CD4+ клітини виявлено у 100,0 \% випадків у туберкульозних вогнищах, у 89,5 \% випадків - у грануляційному шарі туберкульоми та у 72,7 \% - у гранульомах. Відносна кількість цих клітин значно коливалася як в окремих гістологічних структурах, так і в окремих спостереженнях.

Обчислені значення локального імунорегуляторного індексу при активних туберкульомах легень були в межах їх фізіологічних коливань $(1,1-1,61)$.

Висновки. У ділянках легеневої тканини з туберкульомою, де існує безпосередній контакт антигенпрезентуючих клітин з мікобактеріями туберкульозу, найбільша кількість макрофагів із різними морфофункціональними властивостями локалізується в грануляційному шарі туберкульоми, при цьому CD4+ та CD8+ клітини мають значну неоднорідність кількісного розподілу незалежно від кількості інфікованих макрофагів.

Поза туберкульомами у легеневій паренхімі визначаються гранульоми різного клітинного типу-переважають епітеліоїдно-лімфоїдні, також $\epsilon$ макрофагальні та гігантоклітинні. У більшості з них наявні багатофункціональні макрофаги, а кількість CD4+ та CD8+ лімфоцитів значно варіює, що зумовлює зміни імунорегуляторного індексу.

Найменша відносна кількість CD68+ клітин, які водночас інфіковані мікобактеріями туберкульозу (МБТ), спостерігається в туберкульозних вогнищах, при цьому кількість CD4+ та CD8+ клітин варіює. Імунорегуляторний індекс у цих ділянках тканини вказує на переважання цитотоксичної імунної відповіді.

КлючОВІ СлОВА: туберкульома легень; антигенпрезентуючі клітини; мікобактеріальні антигени; імуногістохімія.

Вступ. Лімфоїдні клітини й макрофаги (Мф) $\epsilon$ ключовими клітинними елементами у розвитку й перебігу туберкульозної інфекції. Їх здатність адекватно реагувати на появу $M$. Tuberculosis та її антигенів (АГ МБТ) в організмі людини значною мірою визначає наслідок захворювання. Прогресування захворювання свідчить про неналежний контроль туберкульозної інфекції в ураженому органі на локальному рівні при можливій відсутності будь-яких системних змін імунного статусу. Тому принципове значення має вивчення місцевих імунних реакцій у зоні ураження, зокрема в легеневій тканині з наявністю мікобактерій.

Туберкульома легень (Тб) є однією з форм вторинного туберкульозу, яка являє собою інкапсульоване вогнище казеозного некрозу діамет- 
Огляди літератури, оригінальні дослідження, погляд на проблему, ювілеї

ром більш ніж 1,2 см [2]. Частіше всього Т6 $\epsilon$ наслідком інфільтративного, вогнищевого, дисемінованого чи інших форм туберкульозу легень. Умовою розвитку Т6 $\epsilon$ зниження вірулентності i патогенності туберкульозної інфекції та/чи підвищена резистентність організму до збудника туберкульозу. Тб формується в результаті підвищеної активності фібропластичних процесів і гіперергічної реакції клітинних елементів легеневої тканини у зоні туберкульозного запалення.

Головною морфологічною ознакою мікобактеріальної інфекції $\epsilon$ формування гранульом - компактно організованих скупчень різних імунних клітин, які включають інфіковані і неінфіковані Мф, пінисті та гігантські багатоядерні Мф, епітеліоїдні клітини, а по периферії оточені шаром з лімфоцитів [13].

CD4+ лімфоцити мають принципове значення для контролю мікобактеріальної інфекції у тому сенсі, що з цими керуючими клітинами пов'язане своєчасне формування повноцінних гранульом, як структур, що обмежують розповсюдження інфекції, та цілісність останніх [11].

В експерименті було встановлено, що Т-лімфоцити складають 15-50 \% від усіх клітин гранульом. Приблизно 60-70 \% цих Т-клітин становлять CD4+ лімфоцити, 15-30\% $\in$ CD8+a/ $\beta$ Т-клітинами та приблизно 2 \% складають $ү / \delta$ Т-клітини, у мінімальній кількості наявні натуральні кілерні Т-клітини [9]. Медіатори запалення та антигени мікобактерій сприяють дозріванню дендритних клітин у тканині та стимулюють продукцію інтерлейкіну 12 (IL-12), що приводить до активації Т-клітинної відповіді, в основному, Т-хелперів (CD4+клітини) та цитотоксичних лімфоцитів (CD8+клітини), які забезпечують стримування інфекції. Встановлено, що Т-клітини відіграють ключову роль в активації макрофагів шляхом вивільнення таких речовин, як інтерферон гамма (IFN- $\mathrm{\gamma}$ ) та фактор некрозу пухлин (TNF-a) [10].

Мф $\epsilon$ головною клітиною-нішею організму людини, в якій може перебувати та виживати МБТ. Окрім того, ці клітини відповідають за активацію захисних імунних реакцій як вродженого, так і набутого характеру, які необхідні для контролю та знищення інфекції $[1,7]$. Завдяки експресії багатьох рецепторів на їх мембрані, Мф розпізнають, зв'язують та поглинають чужорідні часточки, у тому числі й МБТ. Добре відомим фактом $€$ функціональна плюрипотентність Мф [3]. На сьогодні Мф умовно розподіляють на 4 основні групи, залежно від їх властивостей у культурі in vivo, хоча їх реальний спектр набагато ширший. Виділяють Мф типів I та II, альтернативно активовані Мф та неактивні $[5-7,12]$. Перші два фенотипи Мф пов'язані з високою бактерицидною активністю, продук- цією ними прозапальних цитокінів (TNF-a; IL-1ß; IL-6), утворенням радикалів кисню, активацією iNOS та синтезом NO. Різниця між Мф I та II типів полягає в різній продукції ними інших цитокінів [7]. Третій фенотип становлять альтернативно активовані Мф, які формуються in vitro за присутності цитокінів Th2-типу (IL-4 а6о IL-13). Також їх утворення стимулюють глюкокортикоїди. Зазначені клітини виробляють деякі протизапальні цитокіни (зокрема, TGF-ß) та знижують Th2-імунну реакцію, ймовірно, шляхом регуляції стимуляції певних лімфоцитів. Альтернативно активовані Мф асоціюються із загоєнням тканини та активністю гуморальної ланки імунітету. Фенотип неактивних (дезактивованих) Мф формується в культурі за присутності протизапальних цитокінів IL-10 а6о TGF-ß, простагландину E2 тощо.

Для оцінки загального стану імунної системи, у тому числі при ТБ, у клінічній практиці використовують імунорегуляторний індекс, тобто рівень співвідношення Т-хелперних клітин до Т-супресорів у периферійній крові [14]. В нормі значення індексу перебуває в межах 1,5-2,5; коли він більший за 2,5, то стан імунної системи розцінюється як гіперергічний, а нижчий за 1,0 - як імунодефіцит. При тяжкому перебігу запального процесу відношення CD4+/CD8+ може бути нижчим за 1,0. Існують дані про порушення імунорегуляторного індексу при ТБ, а саме: його значне зниження у вогнищах специфічного запального інфільтрату до 0,58; а в неактивних гранульомах фіброзної каверни - до 0,75 у легеневій тканині при фібрознокавернозному ТБ за рахунок підвищення кількості цитотоксичних CD8+ Т-лімфоцитів, що свідчить, як вказують автори, про переважання цитотоксичної відповіді, яка супроводжується гальмуванням прозапальної (Т-хелперної) клітинної реакції та подальшим згасанням активної запальної реакції [4]. Дослідження Yin i співавт. [14] виявили значну гетерогенність цього показника в периферійній крові та бронхолегеневому лаважі у хворих з легеневим ТБ залежно від активності процесу, форми ураження, тривалості і впливу протитуберкульозної терапії.

Зважаючи на те, що більшість досліджень антигенпрезентуючих клітин при ТБ у тканинах виконано в експерименті на тваринах, важливе значення має вивчення ураженої легеневої паренхіми людини при різних формах туберкульозу. 3 урахуванням того, що на сьогодні досить поширеною формою Тб легень залишаються туберкульоми, доцільним $\epsilon$, на нашу думку, морфологічне дослідження імунокомпетентних клітин при такій формі ураження.

Мета дослідження - встановити локальні патерни локалізації та відносну кількість анти- 
Огляди літератури, оригінальні дослідження, погляд на проблему, ювілеї

генпрезентуючих клітин, клітин з антигенами M. tuberculosis та величину локального імунорегуляторного індексу в легеневій тканині при активних туберкульомах.

Матеріал і методи дослідження. Проведено імуногістохімічне дослідження серійних зрізів ділянок легеневої тканини на матеріалі 19 резектатів легень хворих із туберкульомою. В усіх випадках встановлено морфологічні ознаки активності специфічного туберкульозного процесу.

Імуногістохімічне (IГX) дослідження проводили на AUTOSTAINER 360-2D виробництва компанії Thermo Fisher Scientific (США), для візуалізації продуктів імуногістохімічної реакції застосовано системy Ultra Vision Quanto HRP DAB. У роботі використано такі моноклональні антитіла фірми Thermo Fisher Scientific (США): мишаче CD4 Clon 4B12, кроляче CD8 Clon SP16, мишаче CD68 Clon KP1 та поліклональне кроляче Mycobacterium tuberculosis antibody PA1-7231 (Pierce Biotechnology, США).

Досліджували ділянки легеневої тканини 3 мікобактеріями та/або їх антигенами, а саме грануляційний шар капсули Тб, туберкульозні вогнища та гранульоми. Мікроскопічне дослідження препаратів здійснювали на мікроскопі Olympus BX51, робоче збільшення 400. Кількість CD68+ клітин та клітин 3 наявністю антигенів M. Tuberculosis оцінювали за умовно прийнятими градаціями: 1 - мало (1-5); 2 - помірна кількість (6-15); 3 - багато (16-25); 4 - дуже багато (більше 25) клітин в одному полі зору.

3 метою визначення відносної кількості CD4+ та CD8+ лімфоцитів у структурах легеневої тканини проводили морфометричні дослідження. За допомогою цифрової фотокамери мікроскопа Olympus при збільшенні ×400 здійснювали фотографування усіх значущих ділянок тканини з ви- користанням програми QuickPHOTO MICRO 2.3. у 5 мікрофотографіях підраховували кількість усіх лімфоїдних клітин та позитивно забарвлених лімфоцитів, далі обчислювали усереднений відсоток CD-позитивних клітин до їх загальної кількості.

Статистичну обробку даних здійснювали з використанням ліцензійних програмних продуктів, які входять в пакет Microsoft Office Professional 2000 (Excel). Розбіжності вважали статистично вірогідними при $\mathrm{p}<0,05$.

Результати й обговорення. У препаратах легень, що досліджувались, капсула Тб була представлена в усіх випадках, гранульоми поза капсулою Тб були визначені у 13 (68,4 \%) випадках, а туберкульозні вогнища - у 10 (52,6 \%) випадках.

У грануляційному шарі T6, гранульомах поза капсулою Т6 та туберкульозних вогнищах, CD68+ клітини та Мф з наявністю антигенів МБТ, тобто інфіковані, були присутні у 100 \% випадків, але кількість цих клітин у різних ділянках тканини була різною. В грануляційному шарі Тб кількість CD68+ клітин була дуже значною, переважали градації «багато» і «дуже багато», у туберкульозних вогнищах переважала градація «помірна кількість», у гранульомах кількість цих клітин значно варіювала, від градації «мало» до «дуже багато».

Лімфоцити субпопуляції CD8 були визначені у 100,0 \% випадків у грануляційному шарі Тб і туберкульозних вогнищах та в 90,9 \% у гранульомах. CD4+ клітини були визначені у 100,0 \% випадків у туберкульозних вогнищах, у 89,5 \% випадків у грануляційному шарі Т6 та у 72,7 \% - у гранульомах.

За допомогою морфометричних досліджень визначено відносну кількість CD4+ та CD8+ клітин у досліджуваних структурах та обчислено локальний імунорегуляторний індекс; отримані дані представлено в таблиці 1.

Таблиця 1. Середні значення відносної кількості субпопуляцій Т-лімфоцитів та локальний імунорегуляторний

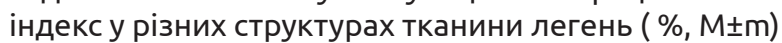

\begin{tabular}{|l|c|c|c|}
\hline \multicolumn{1}{|c|}{$\begin{array}{c}\text { Гістологічна структура, } \\
\text { кількість спостережень }\end{array}$} & СD4+ клітини & CD8+ клітини & CD4+/CD8+ \\
\hline Грануляційний шар туберкульоми, $\mathrm{n}=19$ & $37,9 \pm 3,9$ & $32,5 \pm 3,1$ & $1,2 \pm 0,1$ \\
\hline Капсула туберкульозного вогнища, $\mathrm{n}=10$ & $35,1 \pm 6,8$ & $33,9 \pm 5,2$ & $1,1 \pm 0,1$ \\
\hline Гранульоми на відстані від Т6, $\mathrm{n}=13$ & $42,3 \pm 6,3$ & $29,9 \pm 3,3$ & $1,61 \pm 0,32$ \\
\hline
\end{tabular}

Розраховані величини імунорегуляторного індексу показують, що при Тб легень, навіть при загостренні туберкульозного запального процесу, середнє значення індексу перебуває у межах фізіологічних коливань, оскільки, за раніше опублікованими даними, відношення CD4+/CD8+ у групі здорових дорослих осіб перебуває в межах 0,91-3,17 [8]. Певні відхилення імунорегуляторного індексу було виявлено при дослідженні окремих локаль- них скупчень імунокомпетентних клітин у гістологічних структурах легень з Тб.

Гранулячійний шар туберкульоми. У цій ділянці тканини легень у 6 (36,8 \%) випадках із 19 всі СD68+ клітини мали на своїй поверхні АГ МБТ, відносна кількість цих клітин у різних полях зору відповідала градаціям «багато» - 5 випадків і «помірна кількість» - 1 випадок. В інших 13 (63,2 \%) випадках у тканині були представлені як інфіковані 
Огляди літератури, оригінальні дослідження, погляд на проблему, ювілеї

CD68+ клітини, так і CD68+ клітини, вільні від АГ МБТ. Слід зауважити, що в цих 13 випадках у тканині виявлено максимальну кількість CD68+ клітин у полях зору, відповідна градація «дуже багато».

У грануляційному шарі Тб, у випадках, де були представлені тільки інфіковані CD68+ клітини (5 випадків із 19), відносна кількість CD4+ та CD8+ клітин була нижчою від середнього значення в групі (див. табл. 1), хоча це суттєво не впливало на CD4/CD8 співвідношення, величина індексу була в діапазоні від 0,87 до 1,76. В одному випадку кількість CD4+ та CD8+ клітин значно перевищувала середні значення в групі, імунорегуляторний індекс становив 0,97, а кількість CD68+ клітин у цьому випадку відповідала градації «помірна кількість», що загалом було нетиповим для цієї ділянки Тб.

У випадках, в яких водночас з наявністю інфікованих CD68+ клітин визначалися неінфіковані макрофаги (13 (68,4 \%) випадків з 19), у 5 (38,5 \%) випадках кількість CD4+ і CD8+ клітин була нижчою від середнього значення в групі (див. табл. 1), та імунорегуляторний індекс коливався від 0,68 до 1,47 (відповідно: 0,68; 0,84; 0,87; 0,99 і 1,47, середнє значення - 0,97). В інших 6 (46,2 \%) випадках кількість CD4+ і CD8+ клітин була вищою за середнє значення в групі, імунорегуляторний індекс коливався від 0,77 до 1,63 (середнє значення 1,2).

Таким чином, можна зазначити, що в грануляційному шарі Тб у більшості випадків присутні макрофаги з різною морфофункціональною активністю, а не тільки макрофаги-фагоцити МБТ. CD4+ та CD8+ клітини мають значну неоднорідність кількісного розподілу, причому незалежно від кількості інфікованих макрофагів. Значення імунорегуляторного індексу було дещо нижчим у випадках поєднання поліфункціональних CD68+ клітин у кількості «дуже багато» і зменшеної відносної кількості CD4+ та CD8+ клітин.

Гранульоми поза туберкульомами. Наявність гранульом із центральним казеозним некрозом $\epsilon$ типовою гістологічною ознакою туберкульозу, але при його хронічному перебігу у формі туберкульом легені в ураженій тканині спостерігаються різні клітинні типи гранульом.

Серед усіх гранульом переважали гранульоми епітеліоїдно-лімфоїдного типу та в незначній кількості визначались макрофагальні й гігантоклітинні гранульоми. У 5 (38,5 \%) випадках з усіх 13 в гранульом спостерігали CD68+ клітини з АГ МБТ, причому кількість цих клітин у гранульомах була невелика, переважала градація «мало». В інших 8 (61,5 \%) випадках у гранульомах були визначені як інфіковані макрофаги, так і макрофаги без АГ МБТ; в таких випадках переважали кількісні градації «дуже багато» і «багато» щодо цих клітин.
Стосовно кількісної характеристики субпопуляцій Т-лімфоцитів у гранульомах було встановлено таке. Відносна кількість CD8+ клітин у гранульомах у 7 (53,8 \%) випадках була більшою, а в 5 (38,5 \%) випадках меншою за середній показник групи (див. табл. 1), і в 1 випадку CD8+ клітин у гранульомах взагалі не було. Відносна кількість CD4+ клітин у гранульомах у 6 (46,2 \%) випадках була меншою, а у 4 (30,8 \%) випадках більшою від середнього значення в групі, тоді як у 3 (23,1\%) випадках взагалі не було виявлено CD4+ клітин.

Епітеліоїдно-лімфоїдні гранульоми з центральним казеозним некрозом були визначені у 4 (30,8 \%) випадках. Відносна кількість CD4+ клітин в них була більшою, а CD8+ клітин (у 3 випадках) меншою від середнього значення в групі, що впливало на величину імунорегуляторного індексу його значення було трохи більшим за 2,3, тобто локальний стан імунної системи у цих випадках можна розцінювати як гіперергічний, інакше кажучи, переважала прозапальна імунологічна реакція. у 3 випадках ці гранульоми містили тільки інфіковані Мф.

В інших випадках, коли у гранульомах були визначені як інфіковані, так і неінфіковані Мф, частіше відмічали зменшення відносної кількості CD4+ та збільшення CD8+ клітин, що позначалося на величині імунорегуляторного індексу - він був дещо знижений (відповідно: 0,5; 0,8; 1,0, середнє значення 0,76), що, ймовірно, вказує на переважання цитотоксичної відповіді, яка супроводжується гальмуванням прозапальної (Т-хелперної) клітинної реакції.

Таким чином, у підсумку можна зазначити, що в гранульомах у більшості випадків (61,5 \%) виявлено багатофункціональні CD68+ клітини, їх було "дуже багато», при цьому імунорегуляторний індекс був дещо знижений. Разом з тим, у випадках, коли в гранульомах спостерігали тільки інфіковані макрофаги, значення імунорегуляторного індексу було дещо підвищеним, а за клітинним складом це були переважно епітеліоїднолімфоїдні гранульоми з центральним некрозом.

Туберкульозні вогнища поза туберкульомами. у більшості спостережень у легеневій паренхімі було виявлено туберкульозні вогнища. 3 них у 7 (70,0 \%) випадках вони містили CD68+ клітини 3 АГ МБТ, але, на відміну від кількості цих клітин у грануляційному шарі Тб та гранульомах, відносна кількість їх була меншою, за шкалою градацій переважала «помірна кількість». У туберкульозних вогнищах, де були виявлені тільки CD68+ з АГ МБТ (4 випадки з 7), відносна кількість CD4+ та CD8+ клітин була вищою від середнього показника в групі, імунорегуляторний індекс коливався від 0,8 до 1,28. У 2 випадках значна відносна кіль- 
Огляди літератури, оригінальні дослідження, погляд на проблему, ювілеї

кість CD8+ клітин впливала на величину імунорегуляторного індексу - він був знижений (значення - 0,42 та 0,8), що може свідчити про переважання цитотоксичної відповіді, яка супроводжується гальмуванням прозапальної (Т-хелперної) клітинної реакції та приводить до згасання запальної реакції. У туберкульозних вогнищах, де були присутні як інфіковані макрофаги (CD68+ АГ МБТ+ клітини), так і неінфіковані (3 випадки з 10), відносна кількість як CD4+ клітин, так і CD8+ клітин була меншою від середнього показника, а величина імунорегуляторного індексу коливалася в межах 0,88-1,24.

Загалом можна відмітити, що в туберкульозних вогнищах визначено найменшу кількість CD68+ клітин, порівняно з іншими ділянками легень, які досліджували, причому в більшості випадків ці клітини мали АГ МБТ. Невисокий рівень імунорегуляторного індексу в багатьох туберкульозних вогнищах свідчить про згасання активної прозапальної клітинної імунологічної реакції.

Висновки. 1. У ділянках легеневої тканини з туберкульомою, де існує безпосередній контакт антигенпрезентуючих клітин з мікобактеріями туберкульозу та/або їх антигенами, а саме - грануляційному шарі туберкульоми на межі з некрозом, туберкульозних вогнищах і гранульомах, встановлено виражену кількісну гетерогенність CD4+ та CD8+ клітин незалежно від кількості інфікованих макрофагів у цих же гістологічних структурах.

\section{ЛІТЕРАТУРА}

1. Горлова Е. Е. Патология иммунитета при туберкулезе : обзор литературы / Е. Е. Горлова // Бюллетень физиологии и патологии дыхания. -2010. - № 35. - С. 37-44.

2. Кузик В. П. Патоморфологічні особливості туберкульом легень (за даними аналізу операційного резекційного матеріалу) / В. П. Кузик // Патологія. - 2015. № 1. - С. 99-101.

3. Сахно Л. В. Антигенпрезентирующие клетки при туберкулезе легких / Л. В. Сахно, Е. Р. Черных // Туберкулез и болезни легких. - 2012. - № 1. - С. 3-9.

4. Сорокина И. В. Особенности экспрессии Т-лимфоцитов и оценка иммунорегуляторного индекса CD4/CD8 в очаге специфического воспаления при фиброзно-кавернозном туберкулезе легких / И. В. Сорокина, Т. Г. Филоненко // Таврический медико-биологический вестник. - 2013. - Т. 16, № 3, ч. 3 (36). - С. 135-139.

5. Flynn J. L. Macrophages and control of granulomatous inflammation in tuberculosis / J. L. Flynn, J. Chan, P. L. Lin // Mucosal Immunol. - 2011. - Vol. 4 (3). - P. 271-278.

6. Gordon S. Monocyte and macrophage heterogeneity / S. Gordon, P. R. Taylor // Nat. Rev. Immunol. - 2005. Vol. 5. - P. 953-964.
2. Найбільшу відносну кількість багатофункціональних макрофагів спостерігали в грануляційному шарі туберкульоми.

3. У легеневій паренхімі поза туберкульомою визначаються гранульоми різного клітинного типу переважають епітеліоїдно-лімфоїдні, також є макрофагальні та гігантоклітинні. У складі більшості 3 них також наявні багатофункціональні макрофаги.

4. Найменша відносна кількість CD68+ клітин характерна для туберкульозних вогнищ, причому в більшості випадків ці клітини містять антигени мікобактерій.

5. Визначення величини імунорегуляторного індексу в різних ділянках тканини легень з туберкульомою демонструє відсутність його суттєвих порушень, що опосередковано свідчить про повноцінний імунний відгук при цій формі патології. У незначній кількості гранульом поза туберкульомою індекс характерний для активації прозапальної реакції, а в туберкульозних вогнищах, навпаки, відповідає цитотоксичій імунній відповіді 3 пригніченням прозапальної реакції.

Перспективи подальших досліджень. 3 метою розширення знань щодо контролю туберкульозної інфекції в ураженому органі $\epsilon$ доцільним подальше імуногістохімічне дослідження особливостей клітинного розподілу мікобактеріальних антигенів, макрофагів та субпопуляцій Т-лімфоцитів при різних формах легеневого туберкульозу і за різної активності туберкульозного запального процесу.

7. Guirado E. Macrophages in tuberculosis: friend or foe / E. Guirado, L. S. Schlesinger, G. Kaplan // Semin. Immunopathol. - 2013. - Vol. 35 (5). - P. 563-583.

8. $\mathrm{Cd} 4+, \mathrm{Cd} 8+, \mathrm{Cd} 3+$ cell counts and $\mathrm{Cd} 4+/ \mathrm{cd} 8+$ ratio among patients with mycobacterial diseases (leprosy, Tuberculosis), Hiv infections, and normal healthy adults: a comparative analysis of studies in different regions of India / T. Hussain, K. K. Kulshreshtha, V. S. Yadav, K. Katoch // Journal of Immunoassay and Immunochemistry. - 2015. Vol. 36, No. 4. - P. 420-443.

9. The tuberculous granuloma: an unsuccessful host defence mechanism providing a safety shelter for the bacteria? / M. S. Miranda, A. Breiman, S. Allain [et al.] // Clinical and Developmental Immunology. - 2012. - Vol. 2012. - 14 p. Article ID 139127. - Mode access : doi:10.1155/2012/139127.

10. Activated $B$ cells in the granulomas of nonhuman primates infected with Mycobacterium tuberculosis / J. Y. Phuah, J. T. Mattila, P. L. Lin, Flynn // Am. J. Pathol. 2012. - Vol. 181. - P. 508-514.

11. Prezzemolo T. Functional signatures of human CD4 and CD8T cell responses to Mycobacterium tuberculosis / T. Prezzemolo, G. Guggino, M. Pio La Manna // Frontiers in 
Огляди літератури, оригінальні дослідження, погляд на проблему, ювілеї

Immunology. - Microbial Immunology. - 2014. - Mode access : doi: 10.3389/fimmu.2014.00180.

12. Macrophage receptors and immune recognition / P. R. Taylor, L. Martinez-Pomares, M. Stacey [et al.] // Annual Rev. Immunol. - 2005. - Vol. 23. - P. 901-944.

13. Verma S. K. Pulmonary tuberculoma and miliary tuberculosis in silicosis / S. K. Verma, S Karmakar //
J. of Clinical and Diagnostic Res. - 2013. - No. 7 (2). P. 361-363.

14. The $\mathrm{CD} 4+/ \mathrm{CD} 8+$ ratio in pulmonary tuberculosis: systematic and meta-analysis article / Y. Yin, J. Qin, Y. Dai [et al.] // Iran J. Public Health. - 2015. - Vol. 44, No. 2. - P.185-193.

\title{
REFERENCES
}

1. Gorlova, E.E. (2010). Patologiya immuniteta pri tuberkuleze (Obzor literatury) [Pathology of immunity in tuberculosis (Literature review)]. Byulleten fiziologii i patologii dyhaniya - Bulletin of Physiology and Breath Pathology, 35, 37-44 [in Russian].

2. Kuzyk, V.P. (2015). Patomorfolohichni osoblyvosti tuberkulom lehen (za danymy analizu operatsiinoho rezektsiinoho materialu) [Pathomorphological features of pulmonary tuberculosis (according to the analysis of surgical resection material).]. Patolohiia - Pathology, 1, 99-101 [in Ukrainian].

3. Sakhno, L.V., \& Chernykh, E.R. (2012). Antigenprezentiruyushchie kletki pri tuberkuleze legkih [Antigen presenting cells in pulmonary tuberculosis]. Tuberkulez $i$ bolezni legkikh - Tuberculosis and Lung Diseases, 1, 3-9 [in Russian].

4. Sorokina, I.V., \& Filonenko, T.H. (2013). Osobennosti ekspressii T-limfotsitov i otsenka immunoregulyatornogo indeksa CD4/CD8 v ochage spetsificheskogo vospaleniya pri fibrozno-kavernoznom tuberkuleze legkikh [Features of T-lymphocyte expression and assessment of the immunoregulatory index CD4 / CD8 in the center of specific inflammation in fibrous cavernous pulmonary tuberculosis]. Tavricheskiy mediko-biologicheskiy vestnik - Tavricheskiy Medical and Biological Herald, 16, 3 (36), 135-139 [in Russian].

5. Flynn, J.L., Chan, J., \& Lin, P.L. (2011). Macrophages and control of granulomatous inflammation in tuberculosis. Mucosal Immunol., 4 (3), 271-278.

6. Gordon, S., \& Taylor, P.R. (2005). Monocyte and macrophage heterogeneity. Nat. Rev. Immunol., 5, 953-964.

7. Guirado, E., Schlesinger, L.S., \& Kaplan, G. (2013). Macrophages in Tuberculosis: friend or foe. Semin. Immunopathol., 35 (5), 563-583.

8. Hussain, T., Kulshreshtha, K.K., Yadav, V.S., \& Katoch, K. (2015). Cd4+, Cd8+, Cd3+ cell counts and Cd4+/Cd8+ ratio among patients with mycobacterial diseases (leprosy, Tuberculosis), Hiv infections, and normal healthy adults: a comparative analysis of studies in different regions of India. $\mathrm{J}$ of Immunoassay and Immunochem., 36 (4), 420-443.

9. Miranda, M.S., Breiman, A., \& Allain, S. (2012). The tuberculous granuloma: an unsuccessful host defence mechanism providing a safety shelter for the bacteria? Clinical and Developmental Immunology. Article ID 139127. Retrieved from: doi:10.1155/2012/139127.

10. Phuah, J.Y., Mattila, J.T., Lin, P.L., \& Flynn, J.L. (2012). Activated B cells in the granulomas of nonhuman primates infected with mycobacterium tuberculosis. Am. J. Pathol., 181, 508-514.

11. Prezzemolo, T., Guggino,G., \& Pio La Manna, M. (2014). Functional signatures of human CD4 and CD8T cell responses to mycobacterium tuberculosis. Frontiers in Immunology. - Microbial Immunol. Retrieved from: doi: 10.3389/fimmu.2014.00180.

12. Taylor, P.R., Martinez-Pomares, L., \& Stacey, M. (2005). Macrophage receptors and immune recognition. Annual Rev. Immunol., 23, 901-944.

13. Verma, S.K., \& Karmakar, S. (2013) Pulmonary tuberculoma and miliary tuberculosis in silicosis. J. of Clinical and Diagnostic Res., 7 (2), 361-363.

14. Yin, Y., Qin, J., \& Dai, Y. (2015). The CD4+/CD8+ ratio in pulmonary tuberculosis: systematic and meta-analysis article. Iran J. Public Health, 44 (2), 185-193.

\section{ИММУНОКОМПЕТЕНТНЫЕ КЛЕТКИ И ЛОКАЛЬНЫЙ ИММУНОРЕГУЛЯТОРНЫЙ ИНДЕКС ПОРАЖЕННОЙ ТКАНИ ПРИ ТУБЕРКУЛЕМЕ ЛЕГКИХ С ПРИЗНАКАМИ АКТИВНОСТИ СПЕЦИФИЧЕСКОГО ПРОЦЕССА}

\author{
ФС. Д. Кузовкова, И. В. Лискина, О. В. Хмель, Л. М. Загаба \\ Государственное учреждение «Национальный институт фтизиатрии и пульмонологии \\ имени Ф. Г. Яновского НАМН Украины", г. Киев \\ РЕзЮМЕ. В настоящее время туберкулемы остаются достаточно распространенной формой туберкулеза \\ легких (ТБ). Прогрессирование заболевания может свидетельствовать о ненадлежащем контроле туберкулезной \\ инфекции в пораженном органе на локальном уровне при возможном отсутствии каких либо системных изме- \\ нений иммунного статуса. Вот почему принципиальное значение имеет изучение местных иммунных реакций в \\ участках поражения, в частности, в легочной ткани.
}


Огляди літератури, оригінальні дослідження, погляд на проблему, ювілеї

Цель - установить локальные паттерны локализации и относительное количество антигенпрезентирующих клеток, клеток с антигенами M. tuberculosis и величину локального иммунорегуляторного индекса в легочной ткани с активными туберкулемами.

Материал и методы. Проведено иммуногистохимическое исследование серийных срезов участков легочной ткани на материале 19 резектатов легких больных с туберкулемой и морфологическими признаками активности специфического туберкулезного процесса.

Исследовали участки легочной ткани с микобактериями и/или их антигенами, а именно - грануляционный слой капсулы туберкулемы, туберкулезные очаги и гранулемы. Определяли относительное количество CD4+ та CD8+ лимфоцитов, CD68+ клеток и клеток с наличием антигенов M. Tuberculosis.

Иммуногистохимическое исследование проводили на AUTOSTAINER 360-2D производства компании Thermo Fisher Scientific (США), для визуализации клеток использована система Ultra Vision Quanto HRP DAB. B ра6оте использованы следующие моноклональные антитела фирмы Thermo Fisher Scientific: мышиное CD4 Clon 4B12, кроличье CD8 Clon SP16, мышиное CD68 Clon KP1 и поликлональное кроличье Mycobacterium tuberculosis antibody PA1-7231 (Pierce Biotechnology, США).

Статистическая обработка данных осуществлялась с применением лицензионных программных продуктов, которые входят в пакет Microsoft Office Professional 2000 (Excel).

Результаты. В исследуемой легочной ткани капсула туберкулемы была представлена во всех случаях, гранулемы вне туберкулемы определены в 13 (68,4 \%) случаях, а туберкулезные очаги в 10 (52,6 \%) случаях. CD68+ клетки и макрофаги с наличием антигенов МБТ, то есть инфицированные, выявлены в 100 \% случаев, но количество этих клеток в разных участках ткани было разным.

CD8+ лимфоциты были выявлены в 100,0 \% случаев в грануляционном слое туберкулемы и туберкулезных очагах и в 90,9 \% в гранулемах. CD4+ клетки наблюдали в 100,0 \% случаев в туберкулезных очагах, в 89,5 \% случаев - в грануляционном слое туберкулемы и в 72,7 \% - в гранулемах. Относительное количество этих клеток значительно варьировало как в отдельных гистологических структурах, так и в отдельных наблюдениях.

Рассчитанные значения локального иммунорегуляторного индекса при активных туберкулемах легких были в пределах их физиологических колебаний $(1,1-1,61)$.

Выводы. В участках легочной ткани с туберкулемой, где существует непосредственный контакт антигенпрезентирующих клеток с микобактериями туберкулеза, наибольшее количество макрофагов с разными морфофункциональными свойствами локализуется в грануляционном слое туберкулемы, при этом CD4+ та CD8+ клетки имеют значительную неоднородность количественного распределения независимо от количества инфицированных макрофагов.

Вне туберкулемы в легочной паренхиме определяются гранулемы разного клеточного типа - преобладают эпителиоидно-лимфоидные, а также имеются макрофагальные и гигантоклеточные. В большинстве из них присутствуют многофункциональные макрофаги, а количество CD4+ и CD8+ лимфоцитов значительно варьирует, что обуславливает разные значения иммунорегуляторного индекса.

Наименьшее относительное количество CD68+ клеток, которые к тому же инфицированы микобактериями туберкульоза (МБТ), наблюдается в туберкулезных очагах, при этом количество CD4+ и CD8+ клеток варьирует. Иммунорегуляторный индекс в этих участках ткани указывает на преобладание цитотоксического иммунного ответа.

КЛючЕВыЕ словА: туберкулема легких; антигенпрезентирующие клетки; микобактериальные антигены; иммуногистохимия.

\title{
IMMUNOCOMPETENT CELLS AND LOCAL IMMUNOREGULATORY INDEX IN TISSUE LESIONS AT PULMONARY TUBERCULOMA WITH ACTIVITY OF A SPECIFIC PROCESS
}

\author{
๑S. D. Kuzovkova, I. V. Liskina, O. V. Khmel, L. M. Zagaba \\ F. Yanovskyi National Institute of Phthisiology and Pulmonology, Kyiv
}

SUMMARY. Currently, tuberculomas remain a common form of pulmonary tuberculosis. The progression of disease may indicate about inadequate control of tuberculosis infection in the affected organ at the local level with the possible absence of any systemic changes in the immune status. That's why the study of local immune responses in lesions, in particular in the lung tissue, is of principal importance.

The aim - to establish local patterns of localization and a relative number of antigen-presenting cells, cells with M. tuberculosis antigens and the value of the local CD4/CD8 ratio in the lung tissue with active tuberculomas.

Material and Methods. An immunohistochemical study of serial sections of lung tissue on the material of 19 lung resectates from patients with pulmonary tuberculoma and morphological signs of the activity of a specific tuberculous process was conducted.

Fragments of lung tissue with mycobacteria and/or their antigens, namely, the granulation layer of the capsule of tuberculoma, tuberculosis foci and granulomas were investigated. The relative amount of CD4 + and CD8 + lymphocytes, CD68 + cells and cells with the presence of M. Tuberculosis antigens was determined. 
Огляди літератури, оригінальні дослідження, погляд на проблему, ювілеї

An immunohistochemical study was performed on AUTOSTAINER 360-2D manufactured by Thermo Fisher Scientific (USA), and the Ultra Vision Quanto HRP DAB system was used to visualize of cells. The following monoclonal antibodies by Thermo Fisher Scientific were used: mouse CD4 Clon 4B12, rabbit CD8 Clon SP16, mouse CD68 Clon KR1 and polyclonal rabbit Mycobacterium tuberculosis antibody PA1-7231 (Pierce Biotechnology, USA).

Statistical data processing was carried out using licensed software products that are included in the package of Microsoft Office Professional 2000 (Excel).

Results. In the lung tissue samples the tuberculoma capsule was presented in all cases, granulomas outside of the tuberculoma were defined in 13 (68.4 \%) cases, and tuberculous foci - in 10 (52.6\%) cases. CD68 + cells and macrophages with the presence of MBT antigens (infected) were detected in $100 \%$ of cases, but the number of these cells was very varied in different parts of the tissue.

CD8 + lymphocytes were identified in $100.0 \%$ of cases in the granulation layer of tuberculoma and tuberculosis foci, and in $90.9 \%$ in granulomas. CD4 + cells were observed in $100.0 \%$ of cases in tuberculous foci, in $89.5 \%$ of cases in the granulation layer of TB, and in $72.7 \%$ of cases in granulomas. The relative number of these cells showed significant distinctions in both individual histological structures and in individual observations.

Calculated values of local CD4/CD8 ratio at active pulmonary tuberculomas, were within the limits of their physiological variations $(1.1-1.61)$.

Conclusions. In zones of lung tissue with tuberculoma, where there is a contact of antigen-presenting cells with mycobacteria of tuberculosis, the greatest number of macrophages with different morpho-functional properties are localized in the granulation layer of tuberculoma, while CD4 + and CD8 + cells show significant heterogeneity of quantitative distribution regardless of the number of infected macrophages.

Outside of the tuberculoma in lung parenchyma granulomas of various cell types are determined - mainly epithelioidlymphoid, but there are also macrophage and giant cell domination. Most of them have multifunctional macrophages, and the number of CD4 + and CD8 + lymphocytes varies greatly, which leads to the different values of the CD4/CD8 ratio.

The smallest relative number of CD68 + cells that are simultaneously infected with MBT is observed in tuberculosis foci, and the number of CD4 + and CD8 + cells varies. The CD4/CD8 ratio in these areas of the tissue indicates the prepotency of a cytotoxic immune response.

KEY WORDS: pulmonary tuberculoma; antigen presenting cells; mycobacterial antigens; immunohistochemistry.

Отримано 11.12.2018 